\title{
The Application Research on Scene Teaching of the Pragmatic Teaching System in Modern Vocational Education
}

\author{
Fang Wu \\ Shanghai Publishing and Printing College, Shanghai, China
}

Keywords: Pragmatism, Scene teaching, Studio.

\begin{abstract}
This paper refers to the pragmatic teaching system advocated by international higher vocational colleges. The comparative study of professional scene teaching of the Art Design major is analyzed between University of South Carolina Upstate (USC Upstate) and Shanghai Publishing \& Printing College (SPPC). Through the comparison of similarities and differences in the process of the scene teaching, this paper analyzed the direct influence of the construction of teaching training modes and the teaching system towards the teaching results of the Art Design major in colleges and universities in order to explore the scene teaching optimization model which is suitable for the industry demand of the contemporary society.
\end{abstract}

\section{Introduction}

Pragmatism appeared in the United States in the late 19th century, which was closely related to the social and cultural development of the United States at that time. The formation of the pragmatic teaching system provides the ideological basis for the birth of contemporary university-industry cooperative teaching. Guided by the industrial revolution and empirical science, the attention to the practical value of daily life has become an opportunity for education reform. The pragmatic teaching system constructed by American pragmatist John Dewey (1857-1952) emphasizes the importance of "experience transformation" to teaching and promotes the combination of learning and work. The wave of the reform of education has provided a platform for the practical teaching of the university-industry of Chinese vocational education.

In recent years, vocational education in China has introduced the typical working mode of the industry field into teaching reform, which has been strongly advocated by vocational colleges, especially the Art Design major. The characteristic of Art and Design major makes the studio project teaching mode give full play to its social demands such as projectized teaching content, professionalized learning situations, regulated learning process and socialized learning achievement. In fact, Art and Design professional studio teaching mode is not invented by vocational colleges in our country, many universities abroad have adopted the training modes that focuses on the combination of theory and practice, profession and industry. The western and Chinese style of studio teaching mode can be each other's reference to provide a useful inspiration for the exploration of the teaching mode of Art Design in vocational colleges in China. It is also the purpose of this paper.

\section{Workplace Learning in Context of Foreign Colleges and Universities}

The book Workplace Learning in Context complied by the human resources management lifetime professor Helen Rainbird, explores the role of the workplace teaching in modern education and its influence from four parts: learning context, learning environment, skills and knowledge, research and policy. The workplace concept, especially the vocational education concept, which is introduced into China's higher education, provides all sorts of opportunities for the teaching and practice mainly in the practice environment stimulated by the studio.1 Different from the traditional teaching 
philosophy, modern higher vocational education pays more attention to practice and application, and focuses on the flexible transformation and high adaptability of students' knowledge points in social industries and enterprises. Therefore, the simulation of studio scenes creates a miniature or simplified industrial scene directly for teachers and students. With the new teaching perspective of "lifelike experience" and "active participation", it helps students start their ideas about the future career planning and professional development in advance.

Let's take USC Upstate as an example to analyze the development model of the workplace learning of the Art Design major in foreign colleges and universities.

USC Upstate is a public university in Spartanburg of south Carolina. It was founded in 1967 at the general hospital of Sparta. In 1975, it was approved as a four-year university and set up a graduate degree in 1994. USC Upstate is one of the fastest growing schools in the world. It offers majors like Education, Art Design, Business Administration, Economics, Music, and Literature History. As a teacher and the head of teaching and researching section of Art Design major in a vocational college, the author, as a visiting scholar, once communicated and gave lessons in USC Upstate for a half a year. This public university, which has a history of more than 100 years, has achieved a lot in the construction of the teaching mode of its Art Design studio. In order to fully understand the education mechanism of art in American colleges and universities, and learn more about studio teaching method, the author assisted the core professors of the Art Department to participate in nearly ten specialized courses in the fall semester. In this process, the author took the responsibilities on the students' practice guidance, project discussion, homework review and project evaluation. For the related courses in graphic design, the author was also the master in the course Asia and China History of Art and Design to provide American students with dynamic information and practical examples in design fields in Asia and China. In this process, the following characteristics of the public university studio scene teaching are summarized.
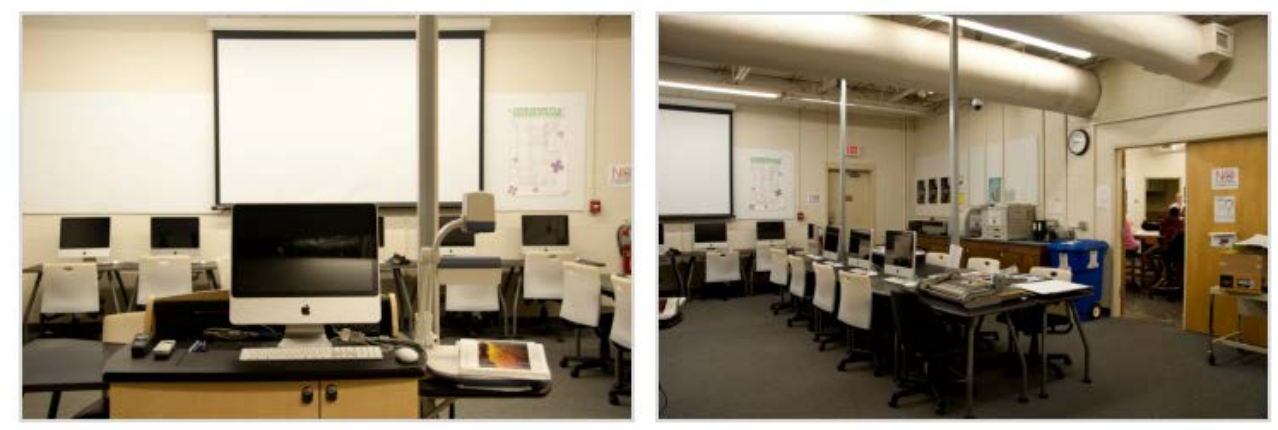

Fig. 1 (USC Upstate) the computer room of the studio

USC Upstate is well prepared for teaching basic equipment. The aim is to facilitate the lectures and realize the teaching objectives. For example, a dedicated Apple computer on the teacher's platform (Teachers needn't carry their own computers; Equipped with wireless network; Teachers can publish comments on students' homework on the Internet at any time; To show the latest information); a projector; a screen facing the platform (convenient to display resources at any time, and show the design in class); speakerphones, laser pens, paper and pens and printing equipments, etc. What's more the student's weekly homework is printed out on the plastic sheets of the wall, and the public leave comments it, including students' comments, self-assessment and teacher summary. The plastic sheets are of great use. They can be used repeatedly, the walls of the classroom are plastered all over the white plastic sheets, which is convenient to show all kinds of information and student homework timely. Picture 1 is the main teaching area. The space is roomy. Each student is equipped with Apple computers and corresponding design software. The teacher has a dedicated computer. When teaching, the teachers and students face the projector together. When discussing, they sit in a circle and carry out communication and interaction face-to-face. The classroom environment has order and vitality, the internal environment of the studio with scene simulation integrates the theory teaching and participation.

The public display space is rich in information, while providing the latest professional information for teachers and students. The public display space of USC Upstate is not very large. It's about two 
classrooms, and make full use of the corridor and other corner space. The information and presentation content is mainly targeted at three items: (1)To report the students' homework and graduation works; (2)To show excellent works of teachers and teachers of other schools; (3) To display excellent designers and artists at home and abroad. It has long established exhibitions, a fixed exhibition hall, and a good platform for teaching and learning, interaction between colleges and universities, and international communication. At the same time, the teacher is responsible for the collection, arrangement and promotion of the theme display, so as to make teaching methods more diversified and teaching information activated. Picture 2 shows the public display space. The facade's cork walls are filled with all kinds of information posters, which have become a unique and enduring landscape in the art studio. Besides providing effective information for students and teachers, it can also construct the bridge of information transmission for the professional teaching and the external social activities and the frontier of industry development.

Setting up senior graduation courses. In USC Upstate, the teachers of specialized courses are responsible for organizing experts and elites of design domain to carry out the graduation guidance courses for senior students. The main content is related to the self-work promotion of graduates, the interview, the overall planning of the project, and the operation specifications of related industries.

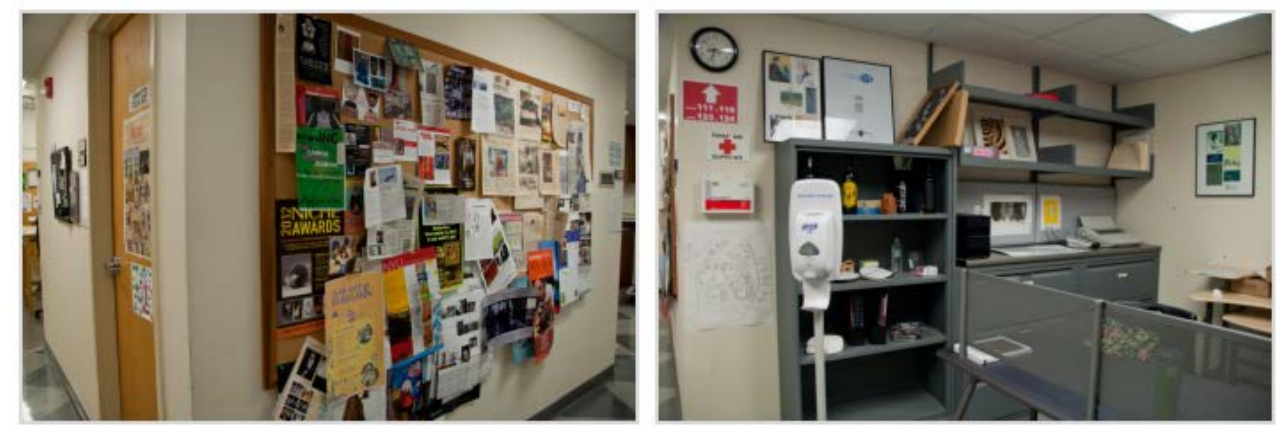

Fig. 2 the public display space of the studio in USC Upstate

\section{The Studio Teaching in Domestic Higher Vocational Colleges}

Let's take Shanghai Publishing \& Printing College (SPPC) as an example, this paper analyzes the progress of the Art Design major of domestic vocational colleges in the workplace learning mode(studio teaching).

In order to adapt to the rapid development of culture creative industry in our country, and change the present situation of lacking talents in the process of creating " Shanghai--the City of Design", the Art Design major of SPPC has timely adjusted the talent training standard and the practical teaching mode in recent years, sped up the reform of the "profession + project" talent training mode carried out by universities and enterprises. It has also further improved the system of "double certificates" and perfected the teaching system of the "project-oriented and dual-certificate combination" modular courses to create the practical model of "studio teaching". The college has gradually built a shared practice and training base for production, training and service. It has built a professional teaching team consisting of specialized teachers and general teachers with "senior titles + advanced craft artists", which is led by the original masters of Shanghai, to enhance the ability to service the society.

Deepen Reform of "Profession + Project + Studio" Talent Training Mode Which Combines Leaning with Work. Based on the new mechanism of the deep integration of colleges and enterprises, SPPC has established a relatively complete training base for internal and external practice, and perfected the practice teaching system. The college takes full advantage of the project studio, college-enterprise cooperation entity, cooperative companies and other carriers to carry out project-oriented teaching. It also deepens the reform of "profession + project + studio" talent training mode which combines leaning with work. Taking the real art design project as the mission carrier, it organizes students to complete the project research, the project design, project technical guidance and other links. During this process, the teaching tasks have been completed. 
The teaching organization model is driven by the task and Oriented by the project. The major cooperates closely with many enterprises to introduce real projects and domestic and foreign art design competitions into the classroom. The teachers lead the students to form the project teams. The teachers are dominant, the students are the main body, they can complete the practical teaching task while completing the project task. The students accept the typical work tasks, and the professional learning is fully integrated into the practical process of the project design, which effectively enhances the students' professional practice ability and professional quality.

In order to cooperate with the task-driven, project-oriented teaching, and implement the docking of the project and the course, the college implements the corresponding teaching plans according to the different requirements of knowledge, ability and quality of different projects. The project is closely connected with the curriculum, and the teaching task is completed during the implementation of the project. In particular, the core courses such as "Book Binding and Sample Design" "Commodity Packaging Design" and "Font Design" are closely combined with projects in the implementation of teaching.

The teaching site is converted from the studio to the company to build the teaching situation based on the working process. In the whole process of project-oriented teaching, the enclosing teaching methods have been gradually changed. Uniting resource of the college and enterprises, the class moves to the studio, the company and other places as the project progresses. For example, during the analysis of the design task, the full-time teacher instructs students to brainstorm, interpret tasks and discuss analysis in the project studio. During the research, the teachers of the college and the leaders of the enterprise's project will communicate with each other. In the stage of project creativity and design expression, teachers and students return to the studio again and use the campus resources to design the plan according to the design requirements. During the program review stage, the classroom moves to the company. Or they ask the company's project leader to review the project in the college. After that, the students revise and improve. After the project's creative design is finalized, it will be guided by the two sides of the college and the company, and will alternate between the company and the studio to complete the design, until the project is completed smoothly.

Actively Promote College-enterprise Cooperation, Invite Industry Experts to the College for Career Guidance. Under the framework of the college-enterprise cooperation council, the Art Design major sets up the school enterprise cooperation council, and enriches the professional construction steering committee. In order to strengthen the guidance of professional construction and talent cultivation and management, construct close and depth cooperation mechanism with college-enterprise cooperation in running schools, cooperative education, cooperative employment, cooperation development, promote the construction of teaching and talent training mode reform, make the professional construction work more active and flexible to meet the needs of industry and society, and serve the industry and social development more effectively, the Art major hires the correlated industry experts off-campus to form the professional construction committee. Every academic year, the enterprise experts will be invited to comment on the students' works, and discuss the cooperation, employment guidance and development of the university. In college-enterprise cooperation conference organized by the school every year, the college and business leaders, part-time teachers together discuss the relevant affairs of work-integrated learning such as the production practice in the companies, the project practice, substituted post exercitation, part-time teachers. The college also coordinate the responsibilities, rights and interests of college-enterprise cooperation, promote the long-term mechanism of resource sharing, joint development, guidance for students and work-integrated learning.

Lead Teaching through "Project-orientation", Institutionalize the Practice with Multi-level and Linkage Ability. To form the institutionalization of the substituted post exercitation of teachers, industries, and enterprises, professional teachers must complete the project of horizontal projects during substituted post exercitation, and teach jointly with part-time teachers of the industry. Specialized courses implement the project as the "true case", and treat the market application as the inspection standard. In line with the teaching philosophy " the first grade with works, second grade with products and third grade with commodities", the college formed the institutionalization of the 
vocational education practice and training. The college uses hardware conditions of the professional studio to strengthen the role of "project orientation" in professional courses. Based on this, the college revised the curriculum system and curriculum standards, waked and improved the teacher's course consciousness, and examined whether the teachers and students have achieved the application standard of practical ability affirmed by the market through the course. See Picture 3.

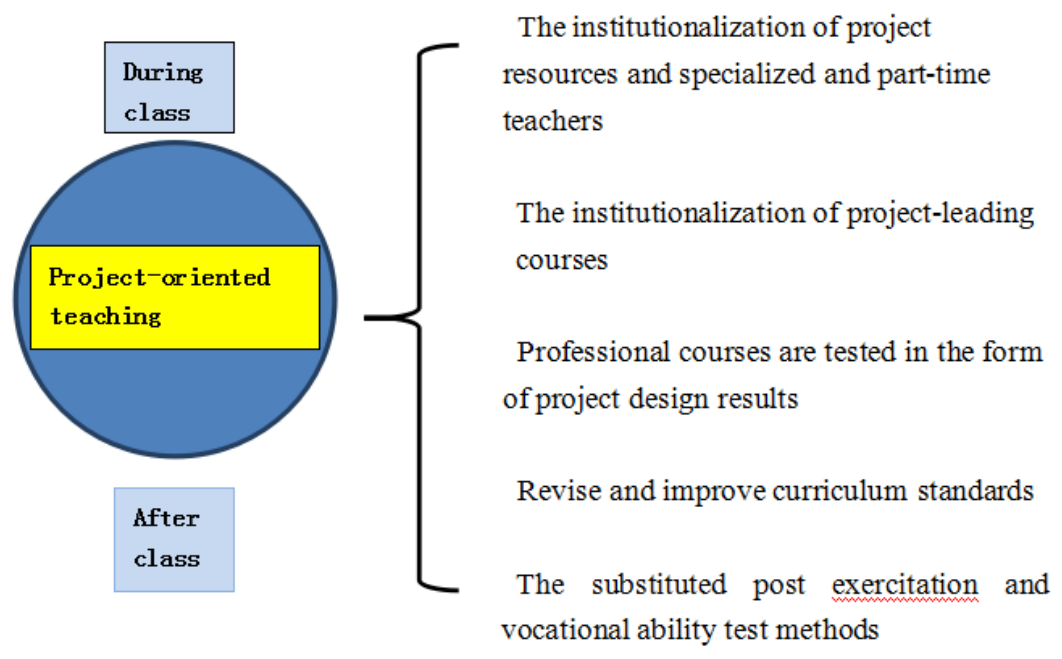

Fig. 3 "Project-oriented" teaching mode

\section{Conclusion}

The cognition in the teaching process is based on experience, which comes from real environment and practical experience. It originates from the foreign scene teaching philosophy and the studio simulation teaching promoted by the domestic professional education in recent years. It connects the new professional knowledge points with the previous knowledge points, and strengthens the cognition experience of teachers and students on the development of the social industry. Fundamentally speaking, the ability of professional education is always contextualized, and thus is referred to as "knowledge in context". As Saul Megherjee, the director of national institute in Rome of Italy , understands that "knowledge in context" is a kind of professional knowledge, there are various efforts and exploration in the programming and automation of teaching in order to solve every specific practical problem. The work situation is closely related to cognitive growth and the development of knowledge demand.

In this paper, the comparison of different teaching modes between Chinese and American Art Design major in professional and scenario-based teaching is based on the comparison of multiple groups. For example, Chinese art teaching with credit + academic year and American credit system teaching, art teaching of higher vocational colleges in China and four-year undergraduate art teaching in America, the single-subject teaching system and multi-subjects parallel system and so on. In today's globalized world, pragmatic teaching has more research and exploration value than any other period in history, especially in the field of professional teaching art design education. In the past, the comparison of education in China and the west was not systematic and unprofessional. This requires a greater amount of attention, output and introduction, to make up for the short supply, and to conform to the development trend of the teaching of Art Design major in vocational colleges.

\section{Acknowledgements}

Project Fund: Education and Scientific Research Project of Shanghai Municipal Education Commission (C17071). Education resource database Project of Shanghai Publishing and Printing College. 


\section{References}

[1] (England) Helen·Rainbird. Workplace Learning in Context [M]. Beijing: Foreign Language Teaching and Research Press, 2011.

[2] K.Ke, Theoretical basis to reform the traditional teaching, Educational research, 1997, pp. 33-36.

[3] W.S. Y, Analyses of the quality problem of the multimedia classroom teaching in colleges and universities, The theory of observation, 2010, pp.8-12.

[4] X.L. Ma and G.Q. Zhao, Common course at the university to flip the empirical study of classroom teaching, Distance education journal, 2013, vol. 1, pp.91-95. 